\title{
Üle piiride liikuvad pered: lood mobiilsusest ja paigal püsimisest ${ }^{1}$
}

\begin{abstract}
Pihla Maria Siim
Teesid: Artiklis analüüsitakse intervjuude abil kogutud materjali kaudu, kuidas hargmaiste perekondade liikmed jutustavad enda või pereliikmete migratsioonikogemustest ning erinevate piiride ületamisest. Samuti on vaatluse all hargmaine pere ja peretunde loomise mehhanismid nii mobiilsete kui ka paigal püsinud pereliikmete vaatevinklist.
\end{abstract}

Märksõnad: hargmaisus ehk transnatsionaalsus, jutustamine, migratsioon, pere, piir

\section{Sissejuhatus}

Migratsioon, identiteet, kuuluvus ja perejutud on võtmekontseptsioonideks siinses hargmaiseid ehk transnatsionaalseid peresid puudutavas uurimuses, milles keskendun Eesti, Soome ja Loode-Venemaa piiriülesele ruumile. Küsin, mida inimesed oma mälestustest kuulajatele avavad ning kuidas nad kasutavad narratiive, et luua identiteeti ja kujundada enda suhteid erinevate rühmade või paikadega nii päritolu- kui ka vastuvõtjariigis. Artiklis keskendun sellele, kuidas inimesed jutustavad rändest, piiride ületamisest ja hargmaisest pereelust, lähtudes jutustajate endi algatatud teemadest intervjuu üldisi eesmärke silmas pidades. Selle põhjal küsin, kuidas mobiilsus perekonda mõjutab.

Mobiilsus - soov ja sund olla mobiilne - ning tegelikud migratsioonitoimingud on olulised teemad nüüdisaegse identiteedi ja inimeste elulugude uurimisel (vt Bönisch-Brednich 2003: 118-119). Üha enam leidub inimesi, kelle elukogemusi ja identiteeti mõjutab elamine erinevates riikides, mistõttu nii mobiilsetel kui ka paiksetel pereliikmetel on järjest rohkem kogemusi riigipiire ületavast pereelust. Ühtlasi aktualiseerib see ka varasemad perelood migratsioonist, kohandades need tänapäevaste kogemustega. ${ }^{2}$

Hargmaisuse uurimine seostub üldisemalt rändeprotsesside uurimisega ja selle kaudu muutuvad oluliseks ka lähimõisted nagu globaliseerumine ehk 
üleilmastumine, globaalsuse ja lokaalsuse omavahelisi pingeid kirjeldav glokaalsus ning võõrsil hajali elavat kogukonda märkiv diasporaa. Diasporaa ja hargmaisuse mõisted kattuvad osaliselt, ent traditsiooniliselt on diasporaa mõiste kitsam kui hargmaisus, või on seda peetud ka üheks hargmaisuse vormiks (Povrzanović Frykman 2004). Kui hargmaisusega viidatakse inimeste, kollektiivide, võrgustike jne riigipiire ületavale tegevusele üldisemalt, siis diasporaa mõistega rõhutatakse kahe või mitme paiga erilist sõltuvussuhet, mis mõjutab oluliselt riigipiire ületanud inimeste elu uues asukohariigis. Algselt on diasporaa mõistega viidatud hajali elavate juutide kogemustele ja vähemalt mingil määral seostatakse diasporaa mõistet endiselt sunnitud migratsiooniga. ${ }^{3}$ Mõistet on siiski laiendatud, viitamaks mitte ainult pagulusele vaid ka migratsioonile laiemalt, sealhulgas postmodernsele kultuuridiasporaale. (Wahlbeck 2002.) Mõte ühisest rühmaidentiteedist, lähteriigist, ühisest kodumaast, tagasipöördumise soov või üldisemalt enda sidumine kindla, geograafiliselt ette kujutletud kodumaaga on siiski selgemini seotud diasporaa kui hargmaisuse mõistega (Huttunen 2002: 44-45; Povrzanović Frykman 2004: 82-83). Ka juhul, kui diasporaa on osutunud ühel või teisel põhjusel püsivaks, võib müüt kodumaast või tagasi pöördumisest mõjuda rühma koos hoidva ning stabiliseeriva faktorina (Safran 1991: 91). Suhe endise kodumaaga võib olla kas kujuteldav või tõeline, aga see on igal juhul tugevalt olemas (Martikainen et al. 2006: 24-25).

\section{Hargmaisus: teoreetiline raam}

Hargmaisus viitab riikide piire ületavatele praktikatele, mis on eelkõige mitteformaalsed ning põhinevad indiviidide, perede ja erinevate mitteametlike rühmade tegevusel. Riikide ja organisatsioonide puhul räägitakse pigem rahvusvahelistumisest või üldisemalt globaliseerumisest. Hargmaisuse täpsemaks kirjeldamiseks saab kasutada kolmetasandilist lähenemist. Makrotasand viitab rahvusvahelistele kokkulepetele, millega reguleeritakse üksikisikute ning rühmade tegevust ning mesotasand viitab ühiskondlikule, organiseeritud kollektiivide tasandile (nt kogukonnad, seltsid ja ettevõtted). Mikrotasandi ehk indiviidi- või peretasandi hargmaisus viitab mitteinstitutsionaalsetele riigipiire ületavatele suhetele. (Vt Martikainen et al. 2006: 24-25.)

Rändeuuringutes keskendutakse üldjuhul kas diasporaale ja võimalikule tagasirändele või rändlejate lõimumisele vastuvõtjariigis. Eeldatakse, et inimesed elavad ja tegutsevad ühes riigis korraga. Nagu Leif Kalev ja Mari-Liis Jakobson on täheldanud, säilitavad rändlejad tavaliselt piiriülesed kontaktid lähedastega päritoluriigis ning elavad korraga kahes reaalsuses. Hargmaisus tähendab seega tavapäraste praktikate laienemist, aga mitte täielikku teisene- 
mist: hargmaistes tegevustes ja piiriülestel väljadel osalev inimene säilitab rolle ka rahvuslikes ja kohalikel tegevusväljadel. (Kalev \& Jakobson 2013: 96-98.)

Oma uurimuses kasutan mõistet transnatsionaalsus ehk hargmaisus. Antud uurimuse kontekstis on see diasporaa mõistest sobilikum, sest intervjueeritute rühm on heterogeenne ja vaatluse all on nii rändekogemusega kui ka koju jäänud pereliikmete kogemused hargmaisusest. Diasporaa mõiste kasutamine võiks ekslikult viidata sellele, et tegemist on ühtse kogukonnaga, keda seob mõte ühisest kodumaast. Transnatsionaalsuse mõiste võimaldab rõhutada, et intervjueeritavate rühm on avatud ka muudes suundades, mitte ainult päritolu- ja sihtriigi suunas. Diasporaa-uuringutes on rühma defineerimisel rõhutatud etnilisust. Antud uurimuses on aga tegu etniliselt erinevat päritolu perekondadega, mille osa liikmeid on endise Nõukogude Liidu aladelt läinud Soome, osa pereliikmetest elab endises elukohas, osa aga mõnes kolmandas riigis. Hargmaisest ruumist kõneldes (vt Faist 2000) viidatakse mitmetele piire ületavatele tegevustele ja kontaktidele, suhtevõrgustikele, mis ei seostu ainult lähte- ja sihtriigiga (kõnelemata sellest, et riigipiirid on vaadeldava rühma elu ajal muutunud).

Hargmaised protsessid paiknevad alati mingis kindlas lokaalses kontekstis. Uuritavad riigid oma ajaloolis-ühiskondliku taustaga moodustavad raamid sellele, mis dikteerivad võimalikud seosed ja kontaktid, mis saavad olla aluseks lugudele ja arutlustele identiteetide üle. Nõukogude Liidu lagunemine ning emigratsiooni reguleerivate seaduste muutumine suurendas rännet Soome (nagu ka teistesse lääneriikidesse) ning ühtlasi siinvaadeldavate hargmaiste perekondade arvu. Piirkonna ühiskondlik-poliitiline olukord ning muutused selles mõjutavad endiselt nii inimeste soovi elukohta vahetada kui ka suhtumist juba ümberasunud sugulastesse, kõnelemata hargmaiste perede tulevikuplaanidest. Rändest hõlmatavaid paiku ja hargmaist ruumi polegi põhjust vaadelda üksteist välistavatena. Hargmaisuse ja diasporaa mõistete abil on proovitud mõista sotsiaalset ja geograafilist ruumi, kus rändlejad elavad ja mida pole võimalik defineerida lokaalset ruumi globaalsele vastandades (Huttunen 2002: 46). Hargmaisus ei tähenda, nagu ei kinnistuks inimesed konkreetsetes piirkondades, kuigi rände tulemusel inimese suhe kohtadega muutub. Liikuvuse kasvades ja rahvusvaheliste suhete lisandudes struktureerib inimeste tegevust sageli pinge, mis tekib liikuvuse ja kohalike kultuuriliste olukordade vahel (Ong 1999: 4-6).

Ametlikes peredefinitsioonides, mida ka statistikat koostades kasutatakse, määratletakse perekonda leibkonnana: pere all mõeldakse inimesi, kes elavad koos ja kel on ühine argielu. Siinses uurimuses märgib pere mitte ainult leibkonda või kahest põlvkonnast koosnevat tuumperet, vaid ka nt täiskasvanuid õdesid-vendi või vanavanemaid, sõltuvalt intervjueeritud inimeste endi arusaamast perest. S.t tegemist on üksteisest (emotsionaalselt) sõltuvate lähisu- 
gulastega. Inimeste liikumisel ühest riigist teise on kujunenud üle riigipiiride ulatuvad pereseosed, hargmaised pered, ${ }^{4}$ mille defineerimisel võib Deborah Fahy Brycesoni ja Ulla Vuorelat järgides pidada oluliseks, et kuigi pereliikmed elavad vähemalt osa ajast üksteisest eraldi, hoiavad nad siiski - vähemalt ideaalis - üle piiride kokku ja toetavad üksteist (nii emotsionaalselt kui ka rahaliselt). Ühes riigis elamine pole seega peretunde säilimise eeldus, kuigi riigipiire ületava peretunde loomisel ja säilimisel on konkreetsest ajast ja ruumist sõltuvad eripärad ja väljakutsed (Bryceson \& Vuorela 2002: 3; Körber 2012: 14). Inimeste liikumine mõjutab ka kodumaale jäänud pereliikmeid ja sugulasi. Hargmaisust uurides on enamasti keskendutud mobiilsete inimeste kogemustele. Sugulaste teise riiki elamaasumisega seoses muutuvad siiski ka koju jäänud pereliikmete elu ja suhetevõrgustikud. Nende kogemustele hargmaisest pereelust tuleks samuti tähelepanu pöörata (vrd Goldert 2001; Körber 2012). Minu eesmärk on uurida nii mobiilsete kui ka paiklike inimeste kogemusi ja sel põhjusel olen teinud mitmepaikseid välitöid, intervjueerides hargmaiste perede liikmeid nii Soomes kui ka lähteriikides. ${ }^{5}$

\section{Uurimismeetod ja materjal}

Rahvusvahelist migratsiooni uurides aitavad kvalitatiivsed uurimismeetodid heita valgust üksikisiku kogemustele ning perede migratsioonipraktikatele, tuues need kategooriate, statistika ning etniliste rühmade üldpildi tagant nähtavale (vt nt Povrzanović Frykman 2008: 17; Chamberlain \& Leydesdorff 2004). Uurin hargmaiste perekondade kogemusi pärimusliku ajaloo vaatevinklist, kasutades narratiivset uurimismeetodit. Narratiivne uurimismeetod lubab, nagu Matti Hyvärinen on kirjutanud, vaadelda lugusid kui mõtlemise, praktika ja sotsiaalse maailma struktueerimisviisi, mitte ainult kui toimunule tagantjärgi subjektiivse tähenduse andmist. Lugude abil on võimalik mõista ja valitseda minevikku, kasutada seda oleviku ja tuleviku vajadusi silmas pidades. Narratiividel on oluline osa inimeste identiteetide loomisel ning jutustamise abil tehakse oma kogemusi teistele arusaadavaks, rajatakse usaldust ja hoitakse rühmi koos. (Hyvärinen 2006: 1-2.)

Keskendun oma uurimuses ${ }^{6}$ hargmaistele peredele Soome, Eesti ja LoodeVenemaa hargmaises ruumis. Mõned intervjueeritavad on pärit ka teistest Venemaa osadest või Baltimaadest, sugulasi elab neil ka kolmandates riikides. Uurimismaterjal koosneb välitööpäevikutest ja neljakümnest (võrdlemisi) avatud intervjuust. Aastatel 2001-2004 intervjueerisin ümberasunud pereliikmeid peamiselt Ida-Soomes. Võimaluse korral intervjueerisin mitut sama pere liiget, sh tegin intervjuusid ka lähteriiki jäänud pereliikmetega (seda Vene Karjalas ja Eestis). ${ }^{7}$ Kokku olen intervjueerinud 31 naist ning 14 meest. 
Mõnega olen kohtunud mitu korda, kas kordusintervjuu tegemise eesmärgil või lihtsalt kohvi- või teetassi ääres. Intervjuudest 29 on tehtud Soomes, 11 Eestis ja Venemaal. Intervjuud on viidud läbi kas eesti, soome või vene keeles (ka mitut keelt vaheldumisi kasutades) vastavalt intervjueeritava soovile. Soome- ja venekeelsed tsitaadid olen tõlkinud selle artikli jaoks eesti keelde.

Soome statistikaamet koondab teavet immigrantide sünnimaa, päritolumaa, kodakondsuse ja emakeele kohta. Statistikaameti andmete järgi oli 2012. aasta lõpus 35,6 protsendil Soomes alaliselt elanud välismaa kodanikest Eesti või Vene kodakondsus. Välismaal sündinutest oli 34,1\% sündinud Eestis, Venemaal või Nõukogude Liidus. Soomes elavatest võõrkeelsetest 37,8\% kõneles emakeelena kas eesti või vene keelt. (Tilastokeskus 2012a; 2012b; 2012c.) Soome statistikaameti andmed ei võimalda vaadelda ümberkolinute etnilist kuuluvust või migratsiooni põhjusi. Sellest tulenevalt on näiteks Soome kolinud ingerisoomlaste arvu kohta raske andmeid saada (vrd Davydova 2004: 48-49; Martikainen 2007: 41). Sisserändajate arv endise Nõukogude Liidu aladelt kasvas märkimisväärselt 1990. aastatel, pärast seda kui Soome päritolu endise Nõukogu Liidu kodanikud võrdsustati 1990. aastal välissoomlastega. Neile anti selle otsusega võimalus taotleda tagasipöörduja staatust ja kolida oma perekondadega Soome. 1990. aastatel endise Nõukogude Liidu aladelt Soome läinud inimestest 60-70\% on ümber asunud tagasipöörduja staatusega, ülejäänud kas töö või õpingute tõttu või perekondlikel põhjustel. Tagasipöördujatena on Soome ümber asunud nii ingerisoomlasi kui ka Soome kodanike järglasi. Enamik endise Nõukogude Liidu aladelt pärit tagasipöördujatest on ingeri juurtega, kellega seostatakse naasmisprogrammi kõige enam. (Vt Liebkind et al. 2004: 22-26; Davydova 2004: 48.) Ingerlased on praegustelt Soome aladelt 17. sajandil ja hiljem ajaloolisele Ingerimaale - tulevasse Peterburi piirkonda - elama asunud inimeste järglased. Paljud sõdade, küüdituste ja repressioonide tagajärjel Ingerimaalt lahkuma pidanud inimestest asusid 20. sajandil elama Eestisse ja Vene Karjalasse. Endise Nõukogude Liidu aladel elab ka teisi soome päritolu inimesi, kes ise või kelle eellased läksid Soomest Nõukogude Venemaale ajavahemikus 1918-1939 ja pärast Teist maailmasõda, ka neil oli õigus taotleda remigrandi staatust. Enne Esimest maailmasõda ümberasunud soomlased olid peamiselt punasoomlased või majanduskriisi tõttu Soomest lahkunud illegaalsed emigrandid, aga ka Kanadast või Ameerika Ühendriikidest 1930. aastatel Nõukogude Liitu kolinud soomlased. (Vt Liebkind et al. 2004: 25-26; Maahanmuutto- ja pakolaispoliittinen toimikunta 1996.) Nõukogude Liidus ei olnud soome keele ja identiteedi alalhoidmine kerge ning paljud pered on mitmekeelsed ja -rahvuselised.

2011. aasta alguses tehtud otsuse järgi on nn ingerisoomlaste naasmisprogramm nüüd lõpetatud, ingerlaste ajaloolisele kodumaale tagasipöördumise õigus on tühistatud ja nad saavad kolida Soome üldistel alustel. Soome asumise 
õigus on säilinud neil, kes andsid oma soovist teada enne 2011. aasta 1. juulit; elamisloa taotlemise tähtaeg on neil viis aastat. Õigus säilib ka nendel ingerlastel, kes evakueeriti Soome 1943. või 1944. aastal ning saadeti sõja lõppedes Nõukogude Liitu tagasi. Niisamuti nendel, kes teenisid Soome armees aastatel 1939-1945. (Välismaalaste seaduse muutmise seadus 57/2011, vastu võetud 25. märtsil 2011 [Laki ulkomaalaislain 48 §:n muuttamisesta 57/2011].)

Minu intervjueeritavad on Soome kolinud mitte ainult oma soome päritolu tõttu, vaid mõned ka õpingute või töö pärast, samuti perekondlikel põhjustel. Sageli on need motiivid ka põimunud. ${ }^{8}$ Tavaliselt nad selgitavad, et on Soome kolinud, tagamaks oma lastele paremat ja turvalisemat tulevikku. Eelistatakse elada ühiskonnas, mida peetakse stabiilseks ja rahulikuks ja kus tulevik on kuigivõrd ennustatav. Ümberasumise põhjustena nimetatakse märkimisväärselt ka majanduslikke olusid. Põhimõtteliselt on tegu vabatahtliku rändega, kuigi ühest piiri vabatahtliku ja sunnitud migratsiooni vahele on kaunis raske tõmmata, eriti 1990. aastate alguses kolinud intervjueeritavate puhul. ${ }^{9}$ Inimesed väidavad, et neil polnud võimalik oma senisesse elukohta jääda. Teisalt ütlevad mõned, et nad on sunnitud jääma oma elukohta, vaatamata soovile ära kolida. Takistuseks on näiteks seadused: väljastpoolt Euroopa Liitu tulevate inimeste puhul loetakse pereliikmeteks, kes saaksid taasühineda, vaid alaealisi lapsi ja abikaasat või elukaaslast. Sellest tulenevalt ei saa täisealised lapsed või (eakad) vanemad tuua Soome kolimise avalduses põhjuseks pere taasühinemise soovi.

Artikli järgnevas osas keskendun väljarändest ja piiride ületamisest jutustamisele neis intervjuudes. Eesmärk on analüüsida, millistele mobiilsuse aspektidele pööravad jutustajad tähelepanu, millises valguses nad räägivad migratsioonist ja enda või sugulaste elust uues asukohariigis. Ühtlasi kontekstualiseerin intervjuudes öeldut, et mõista, millised tegurid esiletoodud aspekte mõjutavad. Pööran tähelepanu piiride rollile inimeste elus ja jutustustes - millist mõju on piirid peredele avaldanud ning kuidas narratiivides piire ületatakse ja kuidas neid konstrueeritakse. Tähelepanu all on ka pere ja selle traditsioonide muutumine ümberasumisega seoses ning jutustamise roll hargmaisusega toimetulekul pere raames.

\section{Lood väljarändamisest}

Intervjuumaterjali läbi töötades jälgisin esmalt seda, kuidas inimesed rääkisid migratsioonist: millistest ümberasumistest jutustatakse, mida rõhutatakse ja millest vaikitakse. See suunas mind keskenduma küsimusele, kuidas inimesed esitavad oma ja võõrast. Ühtlasi tuli ilmsiks, kuidas perejutustusi ja minevikusündmuste tõlgendusi kasutatakse uues olukorras, et luua kontakte ühe või teise rühma või paigaga. Narratiivi käsitletakse siinses uurimuses mitte niivõrd 
kui tulemust, vaid pigem kui protsessi. Proovin pöörata tähelepanu eelkõige sellele, kuidas lugusid kujundatakse. Mõned jutustatud lugudest on selgemalt välja kujunenud, mis viitab sellele, et neid on varemgi räägitud. Vaatluse alla võtsin ka lõdvemalt struktureeritud pereteemalised intervjuuosad, kuna ka need sisaldavad olulist infot inimeste kogemuste ja hoiakute kohta.

Kui rääkida Nõukogude Liidus elanud ingerlaste või soomlaste väljarändeteemalistest narratiividest, meenuvad paljudele esimesena nähtavasti jutud sõjaajast, küüditamistest ja kannatustest, sunnitud migratsioonist ning keeldudest naasta oma kodukohta ka pärast väljasaatmispaikadest tagasi tulekut (vrd Reinvelt 2002). Ka mõni minu intervjueeritav on jutustanud küüditamistest ja sunniviisilisest migratsioonist, tuginedes kas oma kogemustele või viidates teistelt pereliikmetelt kuuldud juttudele. Oma kogemustest rääkinud inimesed on peatunud nendel teemadel veidi pikemalt kui teised, aga enamasti pole need lood siiski kuigi detailsed või elamusküllased. Juhtunule viidatakse napisõnaliselt. Võibolla on see seotud vanemate sooviga keskenduda pere mineviku positiivsematele aspektidele (H29: 7). Teisalt tuleneb see asjaolust, et neid narratiive vaikiti aastaid maha hirmu tõttu autoritaarse riigikorra ees ja nii ei tekkinud tahtmist neid ka edasi rääkida (vrd Davydova 2004: 136), nagu nentis umbes 20aastane intervjueeritav:

Pihla: Kas teil räägitakse tavaliselt palju pere ajaloost?

Taavi: Noh isa poole sugulased räägivad, aga ema poole peal, kus on ingeri päritolu vanaema, see oli mingis mõttes tabu, sest tema, ta käis mõned korrad Siberis, ta ei kasuta ikka veel oma nime [---] sellest ei saanud eriti rääkida ja see jäi kuidagi peale [---] ta ei ole ka palju rääkinud, küllap need on traumaatilised siiski need kogemused. (Mees, kolinud Soome Eestist. H10: 17-18. $)^{10}$

Juttudes sisalduv informatsioon oleks võinud tekitada probleeme, kui need oleksid sattunud perest väljapoole. Mõni intervjueeritav on viidanud ka sellele, et tal on palutud maha vaikida oma etniline taust. Mõnikord on eelistatud sellest mitte rääkida isegi pere ringis. Nagu kõneles üks 30aastane naine, sai tema oma pere ingerisoome taustast teada põhimõtteliselt alles koolis, kui õpetaja pani kirja laste andmeid, sh ka rahvuse (H33: 43). Teine, 51aastane naine jällegi jutustab oma emast, kes oli otsustanud isegi mitte mehele oma päritolust rääkida, mis tekitas peres hiljem pingeid.

[---] ei juletud et, rääkida, et oled ingerisoomlane ja et see on, et minu, ema ei julenud rääkida isale, ja isa oli sellest solvunud ja võib-olla sellest läksidki, võib-olla see oli ka üks põhjus, et läksid lahku, et. Et isa oli solvunud, et kuidas temale ei julenud, ei julge rääkida, ei julenud rääkida ja, ei usaldanud nagu selles suhtes aga, aga eks see elu, mina olen hakanud 
mõtlema, et ikka, et ükskõik, mis niisuguse saladuse sa rä̈̈gid, et ikka võib see kuskilt välja tulla, kogematagi, et ei pea meelega olema. Et tõesti on niisugused suured saladused hea hoida ainult endale, et. [---] isegi seda ei juletud öelda, et Jumal on olemas et, et jälle enne surma mu vanaema ütles et, et Jumal, et Jumal on ikka olemas. Jaa, aga muidu, ei, nagu seda, peeti endale. (Naine, kolinud Soome Eestist. H36: 69.)

Vaikimisel on olnud ennekõike kaitsefunktsioon. Noorem põlvkond ei ole ka kuigi hästi kursis nende peret puudutanud varasemate sündmustega. Teisalt, nagu mõned uurijad on osutanud, tekkis 1990. aastatel võimalus kogetut jälle avalikult meenutada. Sõjal ja ingerisoomlastele osaks saanud raskel saatusel on rühma jutustamistraditsioonis olnud kindel roll (Reinvelt 2002). Sellegipoolest ei ole need lood eriti noorema põlvkonna intervjuudes kuigi olulisel kohal, sest esil on uutest elumuutustest jutustamine. Mõned intervjueeritavad on perepärimuse juurde jõudnud hoopis kooli ajalootundides äratatud huvi tõttu. Tunnis õpitu ajel on nad hakanud ka (vana)vanemate käest täpsemalt uurima oma pere mineviku kohta (H27: 23-24). Osa vanema põlve intervjueeritavatest on avaldanud kahetsust, et nad ei tundnud huvi perejutustuste vastu ajal, kui vanem(ad) oleks(id) neid rääkinud, ning kardavad, et ka nende (lapse)lapsed hakkavad lugude vastu huvi tundma alles siis, kui on juba liiga hilja.

Pihla: A kas, kas nad sellest on huvitatud, et missugune nende isa oli väiksena, või selliseid jutte?

Heli: Mitte keegi ei ole küsind midagi. Nad on isegi, ma olen mitu korda neile etteheiteid teinud et, et tuleb nagu mullegi ette see, et kui ma olin noor ja mul ju ema elas, isa suri ka varakult ära, aga ema elas, et kui palju asju ma oleks võind ema käest küsida, mida ma ei oskand siis küsida. Aga et nüüd ma, mul tuleb palju asju ette, ema ei ole ammu enam, kuidas ma, mida ma võiks ammu kõike küsida, aga enam pole, kelle käest küsida. Ma ütlesin, et teie olete ka nü̈̈d, viidate selle aja kõik ära, terve, terve mu elupuu, terve mu suguselts on niimoodi läind, et keegi ei tunne enam kedagi. Kõik jäävad võõraks. Ja-ja minu, minu elu, noorusajast mitte keegi ei tea midagi, ei tunne üldse huvi, ei küsigi. Ja see on mul natuke nigu väga valus koht igatahes. (Naine, elab Eestis. H39: 129.)

Hiljuti läbielatud väljarändest seevastu jutustatakse hea meelega; oma kogemust soovitakse avada minule kui intervjueerijale, keda võetakse kui enamuse esindajat. Tihti võib narratiivi taustal näha ka soovi seletada oma kogemust laiemale ühiskonnale: publiku all ei ole siinkohal mõedud ilmselt ainult mind kui uurijat. Mõlemat tüüpi jutustusi - nii lugusid sunnitud migratsioonist kui ka viimaste aastate või aastakümnete jooksul läbitud teekonnast - läbiv element on hakkama saamine või "ellujäämine", kuigi seda üsna erineval tasandil. 
Kui vaadelda intervjueeritud inimeste väljarändeprotsessi jutustustes, on üheks lugusid ühendavaks teguriks ahelmigratsiooni mustri jälgimine rändlejad eelistavad kolida piirkonda või linna, kus on ennast juba varem sisse seadnudmõni nende sugulane või tuttav, kes aitab uustulijal järje peale saada (vrd Bryceson \& Vuorela 2002: 21). Mitmed intervjueeritavad räägivad, et alguses elasid nad sugulaste juures. Samuti räägitakse teistest olulistest inimestest sõpradest, tuttavatest ja isegi ametnikest -, kes on aidanud intervjueeritavaid Soomes nende sealviibimise esimeste nädalate või kuude jooksul. Niisugustel abistajatüüpi tegelastel on väga tähtis roll väljarändelugudes. Juhtub, et näiteks sotsiaalametnikke mainitakse intervjuudes nimepidi.

Soome kolimise põhjustest rääkides tõstavad intervjueeritavad esile enamasti kas (ingeri)soome juuri või turvalisema ja stabiilsema elu otsingu. Remigrandi staatusega Soome kolinud inimestel on üldiselt kalduvus rõhutada Soome juuri, kokkukuuluvust Soomega (vrd Davydova 2002: 164), õigustamaks end ümbritseva ühiskonna ees kui etnilisele kodumaale ümberasujat. ${ }^{11}$ Selles kontekstis tundub veidi üllatavana ümberpaiknemise praktilise külje rõhutamise suur osatähtsus intervjuudes. Paljud jutustavad, kuidas nad on tulnud õppima või tööle, ning ka Soome päritolu intervjueeritavad ei too esile oma tausta isegi juhul, kui see on hiljem võimaldanud neile juriidilise õiguse Soome jääda. Võib-olla tahavad nad rõhutada hakkamasaamist, jättes endast pigem tööka ja toimetuleva inimese mulje, eeldades, et tööle või õppima tulnuid võetakse ühiskonnas paremini vastu. Ühelt poolt kirjeldavad intervjueeritavad Soome tulekut kui juhust ("nii lihtsalt juhtus"). Teiselt poolt on märgata, et nad konstrueerivad ümberpaiknemisest mõtestatud-läbikaalutud narratiivi. Sellistes narratiivides kujutatakse migratsiooni planeeritud tegevusena kui läbimõeldud otsuse tulemust. Siiski on võimalik, et migratsioon on kujunenud kavatsuslikuks või tähenduslikuks tagantjärele, sellest jutustades. Nagu Brigitte Bönisch-Brednich (2003: 127) kirjutab, luuakse immigratsioonilugusid selleks, et kohaneda muutustega, näha migratsiooni positiivsena ja tunda end oma tunnetes kindlana. Vahest see kindlus sünnib just tagantjärgi, aastaid pärast kolimist. ${ }^{12}$

Neid mõlemaid tendentse - viiteid nii juhuslikkusele kui ka kaalutletud otsusele - on võimalik leida isegi ühest ja samast intervjuust, nagu on märgata 59aastase Vene Karjalast Soome kolinud ingeri päritolu naise loos (H16: 9, 52). Esialgu Helmi märgib, et ei olnud mingit konkreetset otsust või plaani kolida, ta lihtsalt juhtus seda tegema. Helmi kolmest lapsest kaks olid juba varem kolinud Soome, esialgu õppima ning seejärel tööle. Ta järgnes lastele, läks nendele appi, kui neil olid oma elus rasked ajad. Helmi mees ei tahtnud kolida, kuid hiljem ta siiski järgnes perele. Sama intervjuu edenedes selgitab Helmi siiski, et ta kolis kasvava kindlusetuse, ebakindla tuleviku tõttu. Ta jutustab korduvatest sissemurdmistest nende koju Venemaa Karjalas, vargustest aiamaal, 
varastatud paatidest. Ka tütar kirjeldab ema põhjalikku ettevalmistust Soome tulekuks (H33: 169). Helmi intervjuust tundub, et kuigi jutustaja loob sidemeid Soomega, on tema loos siiski tähtsam endisest kodumaast vabanemine. Sellele osutab kodumaale mitmete negatiivsete tunnuste omistamine. Emotsionaalne distantseerumine endisest elukohast võib olla vajalik selleks, et luua sidemeid uue kodumaaga (Davydova 2004: 254-255). Uue kodumaa valikul ei rõhuta Helmi kuigi palju oma ingerisoome päritolu, vastupidiselt oma tütrele, vaid toob esile peresidemed, vajaduse olla oma laste ja lastelaste lähedal.

Rändelugudega on huvitav võrrelda nii Soome kolinud pereliikmete kui ka nende päritoluriiki jäänud sugulaste räägitud narratiive esimestest Soome-reisidest. Intervjueeritavad on üpris tihti kirjeldanud naabermaa või esivanemate kodumaa esimese visiidiga seotud tundeid ja kogemusi. Mõningatel juhtudel räägivad need jutud kohtumisest millegi võõraga, mille pärast inimesed oleksid tahtnud esimesel võimalusel koju tagasi pöörduda. Teised jällegi leiavad Soomega kontakti näiteks ühise, juba lapsepõlves omandatud keele kaudu. Paljude soome päritolu ümberasujate kodukeel ei ole soome keel, kuid on neid, kelle vanavanemad kõnelesid soome keeles ja nad kuulsid soome keelt vanavanemate juures veedetud ajal. Näiteks ingeri päritolu üle 50aastane naine Terttu rääkis oma esimesest Soome visiidist järgmiselt:

Esimene kord, kui sõitsin välismaale, ka mina muretsesin väga, sest see oli esimene kord. Aga kui jõudsime kohale, seal oli üks tüdruk [naerab], mängis koeraga ja riidles koeraga millegipärast, ja vaat siis meenus mulle see lapsepõlve keel. Vaat see, miski [nagu] koore alt, see, mis lapsepõlves oli, selline tuttav, selline omane, et tundub [keegi naerab], nagu oleks see sama, mis oli meil lapsepõlves, just seesama keel, kõik sõnad olid arusaadavad, kõik oli selge. Kuidagi rahulik hakkas. (Ingeri päritolu naine, elab Vene Karjalas. H31A: 35.)

Mõnes rändenarratiivis on kohanemist hõlbustava tegurina nimetatud suguvõsa soome juuri ja lähedustunnet soome keele ja kultuuriga. Perelugude ja traditsioonide abil on loodud järjepidevust identiteedile, kuigi soome tausta ja traditsioone Nõukogude Liidus tihtipeale väljapoole pereringi ehk avalikus ruumis ei esitletud. Pere oli koht, kus sai etnilisust alal hoida. Terttu ja osa tema õdesid-vendi ei ole oma ingerisoome taustast hoolimata tahtnud Soome kolida. Nende hinnangul on ümberasumine eelkõige mõttekas noortel. Nende enda elu on möödunud Vene Karjalas, juured ja "kõik" on seal olemas. Soomes on hea külas käia, aga kodus on parem (H31: 31-33).

Narratiivid 1990. aastate alguses aset leidnud ümberasumisest meenutavad omadustelt kõige rohkem seiklusjutte. Väljaränne tähendas paljudele sõna otseses mõttes hüpet tundmatusse - nad jätsid kõik selja taha, tagasiminek ei oleks enamasti mõeldav olnud. Piiri ületamine polnud nii lihtne nagu täna- 
päeval, kahe riigi vahel pendeldamine ei tulnud veel kõne alla, ja see kujundas ka suhteid lähteriiki jäänud sugulastega. Toon kokkuvõtte ühest ulatuslikust ja emotsionaalsest loost, mis on liiga pikk (peaaegu 4 lehekülge litereeritud intervjuust) siin täismahus tsiteerimiseks. Jutustaja, 40aastane Tanja elas lapsepõlves Eestis. Pärast abiellumist 20aastaselt läks ta elama abikaasa juurde Venemaale. Nad olid Peterburis peaaegu 10 aastat. Nende peres kasvas kolm last. Tanja kirjeldab detailirikkalt pere kolimist Soome, mis tuli veidi üllatusena ka talle endale. Oma loos rõhutab ta juhuslikkust ja sündmuste kiiret kulgu. Ta nimetab sündmuste arengu seisukohalt mitut olulist isikut nimepidi, näiteks Soome kutse saatjat ning Ingeri liidu töötajat, kes pakkus ümberasumise võimalust. Tanja jutust võib aru saada, et esialgu oli tema mees elukoha vahetamisest rohkem vaimustatud ning koguni Soome kolimise initsiaator. Mõned aastad pärast Soome kolimist abielupaar siiski lahutas ja mees suundus tagasi Peterburi. Elukoha vahetamine on enamasti pere ühine otsus, ent selle mõju pereliikmete omavahelistele suhetele on raske ette ennustada.

Käisin soome keele kursusel Peterburis, lihtsalt huvi pärast, meil ei olnud mingit kolimise plaani, ma ei olnud isegi kuulnud, et ingerisoomlased saavad Soome kolida. Siis ma järsku kuulsin, et mu nõbu läks Soome, ta oli esimeste lahkujate hulgas. Aga ta kolis kuidagi, ei öelnud kellelegi midagi, ma ei tea mispärast. Me elasime kohe Soome vaksali kõrval. Iga hommik kuulsin rongi saabumist ja väljumist, nad mängisid mingit rahvalaulu kogu aeg. Ma kuulsin seda ja mõtlesin, et oleks kihvt Soomes käia millalgi, aga ma ei mõelnud kunagi, et kolida, minna elama sinna. Mu mees oli taksojuht. Ükskord üks tütarlaps võttis takso ja rääkis talle, et ta elab Soomes soome mehega. Mu mees kasutas kohe juhust ja ütles talle, et ta naine on soomlane ja palus tal vormistada kutse meie jaoks, et Soomet külastada. Läksin kutsega Ingeri liitu nõu küsima, ma ei olnud kunagi käinud välismaal. Seal oli see Leila, vaatas mu passi, kus oli kirjas "soomlane" ning küsis mu käest, kas ma ei tahaks Soome kolida. Lihtsalt proovida, kas mulle meeldib seal. Ütlesin, et pean oma mehe käest küsima. Ta andis aja konsulaati, see oli vist kolm päeva hiljem. Kõndisin koju ja nutsin. Muidugi tahtis mees minna. Kolme kuu pärast olime juba Soomes. Me läksime väikse Moskvitšiga, järelkäru oli ka asju täis. Sõitsime umbes 16 tundi, meil ei olnud isegi Soome kaarti. Meil oli 300 Soome marka, meie sõber ütles, et meil pole midagi vaja. Tol ajal polnud isegi võimalik välisvaluutat kodus hoida. Oli miinus 30 kraadi, Vene tollis läks viis tundi aega, väikeste lastega. Pidime lahti pakkima kõik asjad, mis meil kaasas olid, mul on pilt ka kuskil. Soome tollis nad lihtsalt soovisid meile head reisi. See oli imeline tunne. Meie Raissa läks vetsu seal ja ka tema ütles kohe: ema, mulle meeldib Soomes. Nii me siis 
saabusime, olid jõulud. Me tähistasime alati jõule, aga ma ei taibanud, et ei olnud hea mõte teel olla 26. detsembril. Mitte keegi ei olnud tööl. Me läksime politseijaoskonda, järgmisel päeval tööjõubüroosse, siis sotsiaaltööbüroosse. Ma ei rääkinud soome keelt eriti hästi, aga meil ónnestus hakkama saada - nagu pimedad kassipojad. Ma ei saanud aru, miks meil oli vaja minna sotsiaaltööbüroosse. Nad arvutasid midagi, ütlesid et me peame panka minema, siin on 5000-margane tšekk. Ma peaaegu surin. See oli meie jaoks nii suur summa. Ja ma kartsin seda kasutada, sest ma ei teadnud, millal ja kuidas me saaksime jälle raha. Lapsed olid üllatunud, nähes nii palju värvilisi asju poodides, nad ei olnud harjunud sellega. Me saime suurema korteri siis, kui õppisin rääkima soome keelt. Peterburis olime elanud, viis inimest ühes toas. Inimesed aitasid meid Soomes palju. Raissa õpetaja organiseeris meile mööblit ja inimesed tõid meie lastele ka mänguasju. Üks päev, kui me tulime koju, ootas ukse taga kaks kilekotitäit Barbisid. Ma arvasin, et mu tütred lähevad hulluks. Venemaal oli neil ainult üks Barbi. Mu lapsed olid nii õnnelikud. Järsku oli neil kõike, oma tuba, nukke, kõike, nad olid päris õnnelikud. Selline oli meie kolimine. (Ingeri päritolu naine, elab Soomes. H8: 8-9.)

Sageli kirjeldatakse oma esimesi muljeid Soomes ning ümberasumisega kaasnenud üllatusi, nii positiivseid kui ka negatiivseid. Rõhuasetus sõltub sellest, kas ümberasumist hinnatakse õnnestunuks või mitte. Intervjueeritavad nimetavad tihtipeale neid Soome algusaegadel aidanud inimesi, kuid mõnikord rõhutatakse nimelt seda, et nad on algusest peale ilma abita hakkama saanud - eelkõige käib see sotsiaaltoetuste kohta. Märkimisväärne Tanja loos on see, et intervjueeritav kirjeldab migratsioonikogemust ja sellega seotud tundeid oma laste kaudu. Arvestades seda, et väljarändamist on tihti põhjendatud tõigaga, et see on parim lahendus laste tulevikule mõeldes, pole see siiski nii üllatav. Pealegi võib oma tundeid olla raske kirjeldada või analüüsida. Kergem on rääkida laste reaktsioonidest. Teisalt elatakse laste kogetud tagasilööke valusamalt üle, kui ümberasumise eesmärk on olnud just nende elu paremaks muutmine.

Oma lugude kaudu suhestavad rändlejad ennast üldiste immigratsiooni ja immigrante puudutavate diskursustega. Jutustades võivad nad justkui vaidlustada üldisi arusaamu, mida nad eeldavad ühiskonnas levinud olevat, või kinnitada neid. Neid eeldatavaid arusaamu võib aimata jutustuste "taga" olevatest sõnastamata seisukohtadest. Näiteks on endise Nõukogude Liidu aladelt Soome kolinud heterogeenses rühmas soomlastega abiellunud naised üsna madala staatusega - nii rühma-siseselt kui ka ühiskonnas laiemalt. See kontekst aitab mõista viisi, kuidas soome mehega abiellunud 45aastane Oksana enda Soome tulekust räägib. Oksana lugu erineb paljuski eeldatavast või stereotüüpsest Soome kolinud ja soomlasega abiellunud vene päritolu naise loost. Ta peab vajalikuks rõhutada, et tal oli Venemaal juba "kõik" olemas - ta 
ei tulnud Soome otsima paremat elu, nagu tavaliselt eeldatakse. Algul Oksana isegi ei kavatsenud kolida. Aga siis ta armus ja jättis endise elu, oma ema ja 14aastase lapse Venemaale, et avastada - elu soome mehega polnudki selline, nagu ta oleks oodanud, ning kuus aastat hiljem nad lahutasid.

Tulin [Soome] kaheksa aastat tagasi. Oma elukutselt olin inglise keele õpetaja. Viimasel ajal olin töötanud ekspordi-ja impordijuhina väikses Saksa ettevõttes, pärast Ameerika firmas. Olin väga rikas naine, minul oli kõike. Palju raha, kaks kodu. [---] Siis armusin soomlasesse ja jätsin kõik ja tulin Soome elama. [---] Ma ei tahtnud Venemaalt ära tulla. Paljud tahtsid välismaale saada, aga mina ei tahtnud. Mul oli kõik [olemas]. Olin nii rikas, mul oli oma autojuht, oma koduabiline ja mul polnud midagi vaja. Võib-olla vajasin ainult kogemust, et minu elu ei olnud nii raske, olin kui laps, mõtlesin, et elu on minu jaoks, kõik on lihtne, kõik on kena. Arvan, et elu Soomes oli päris karm, aga vajalik õppetund minu jaoks. Mul on tegelikult hea meel selle üle. Kuigi vahepeal on päris raske. (Naine, kolinud Soome Venemaalt. H3: 2, 20.)

Paljud asjad Oksana elus ei ole Soomes läinud nii, nagu ta eeldas. Oksana jutustab, et tema abikaasa ei tahtnud, et ta õpiks soome keelt või käiks tööl. Lisaks oli mees hiljem ka vägivaldne. Mõnes mõttes võib Oksana loos täheldada vaikse allaandmise elemente, teisalt ei kavatse Oksana alistuda. Ta on tõlgendanud oma negatiivseid kogemusi positiivsel moel, öeldes, et need olid tegelikult vajalikud etapid tema elus, tagamaks sisemist kasvu, muutmaks teda paremaks inimeseks. Võib väita, et ta on ebaõnnestumistest kujundanud enda jaoks positiivse (võtme)narratiivi (vrd Kaivola-Bregenhøj 2008), millel on tema enda silmis eriline tähendus ja mille abil on võimalik lootusrikkalt ka tulevikku vaadata. Ühtlasi on Oksanale muutunud tähtsamaks ka religioon: ta on unistanud isegi kloostrisse minekust, ta ainult ootab, et ta noorem laps suuremaks saaks.

\section{Laste ja päritoluriiki jäänud sugulaste vaade}

Migratsiooni vaadeldakse enamasti just täiskasvanud rändlejate vaatevinklist (hinnates kohanemist vastuvõtva ühiskonnaga). Mitmekesisema pildi saamiseks otsustasin heita pilgu erinevate pereliikmete lugudele, võrreldes täiskasvanud migrantide lugusid noorte ümberasujate ning ka päritoluriiki jäänud sugulaste jutustatud lugudega - nad kõik näevad ümberasumist veidi erineva nurga alt.

14-20aastaste laste räägitud lugudes on ümberasumise spontaansust ja ettearvamatust rõhutatud rohkem kui täiskasvanute intervjuudes. Suures 
osas on see tingitud asjaolust, et kolimise otsuse on vastu võtnud vanemad. Lapsed on lihtsalt järgnenud neile. Paljudel intervjueeritutest, kes kolisid kas lapsena või noorukina, ei ole ümberasumisest konkreetseid mälestusi, kuigi nad on maininud näiteks mälupilte piiril seismisest külmal talvepäeval, ning hämmeldust poodides, kus oli kõike uut ja ilusat (viimasel juhul on jutt perest, kes kolis Soome 1990. aastatel). Noored on jutustanud pigem sellest, kuidas nad Soomes omal ajal kooli läksid, oskamata sõnagi soome keelt. Tuleb ette ka seda, et murdeealisi lapsi on tahetud lähteriiki vanavanemate juurde tagasi saata - eemale sõpradest - kui nad Soomes on pahandustesse sattusid. Toon näite Soome kolimise kirjeldusest intervjuu ajal 17aastaselt Katjalt, kes oli Soome tulnud umbes kaheksa aastat enne selle intervjuu tegemist. Pereisa ja Katja õde elasid tol ajal juba Soomes, aga erinevates piirkondades. Kolimine oli Katjale täielik üllatus: ta ema otsustas koju tagasi mitte pöörduda, kui nad Soomes puhkust veetsid. Katja ema rõhutas oma loos (H1: 11) seda, et ta proovis kuni viimase võimaluseni elada lastega Venemaal. Kuna kodumaal palka regulaarselt välja ei makstud, raha saadi 2-3 kuu tagant, survestas abikaasa teda kolima Soome. Konkreetset ümberasumissituatsiooni ta intervjuu vältel ei kirjelda.

Pihla: Millised olid kõige suuremad muudatused sinu elus seoses Soome kolimisega? Kas sa tahtsid siis kolida ja mida sa mõtlesid [enne kolimist] ja kas see oli kuidagi teistmoodi siis?

Katja: Tegelikult seda polnud üldse planeeritud, me tulime siia emaga külla niisama, suvepuhkuseks. Ja siis ema otsustas, et võtame ja saadame meie passid sinna viisa-, või sinna tolliametnikele, või mis see on, et nemad pikendaksid viisasid. Ja sinna need passid jäid. Siis tuli aeg kooli minna ja ema ütles, et proovi käia koolis siin [P. naerab]. Niiviisi üsna kiiresti tuli [see otsus]. Ja nii ma proovin, ikka veel [naerab]. [---] See oli selline väga spontaanne kolimine. Ei planeeritud midagi. Alguses oli ikka väga raske, kolisin veel sellisesse ümbrusesse, kus ei olnud ühtegi venelast ja polnud harjutud võora kultuuriga. Kõik vaatasid sellise pilguga, et mis sa siin teed ja mis kõike. Oli just selline vanus, et oleks vaja suuremat õde ja kõike, just pidin temast lahku minema, see oli päris ränk.

Pihla: Kas su õde jäi tollal, et ta ei tulnud?

Katja: Jah. See oli niiviisi, et kõigepealt kolis ta siia, 16aastaselt [---]. Ja siis, ta elas siin natuke alla kahe aasta, ei pidanud rohkem vastu ja kolis sinna [Venemaale tagasi], ja siis just meie kolisime siia. Nagu vahetanuks rolle. [---] (Naine, kolinud Soome Vene Karjalast H2: 15-16.)

Vanemal õel oli Soome eluga raske kohaneda, sest ta tuli Soome ilma pereta. Katja tunneb, et ka temal oleks kohanemisel vaja olnud suurema õe tuge. Tsitaadis ning intervjuus üldisemalt rõhutatakse pere rolli, aitamaks uue kesk- 
konnaga kohaneda: "just see pere tähendus selles etapis, et pidada vastu selles olukorras, olla võimeline kohanema, kuna tead, et ei ole üksinda, et on keegi toetamas, see on väga suur asi” (H2: 58). Katja leiab, et raskused on teda emaga ühendanud. Teisalt on ema ootused tema suhtes väga kõrged, ema rõhutab hea hariduse omandamise tähtsust ning mõnikord on Katja tundnud, et surve ja ema ootused on muutunud mõneti koormavaks.

Intervjuumaterjalides leidub palju näiteid lugudest, kus kirjeldatakse hakkamasaamist raskustest hoolimata. Nende lugudega proovitakse julgustada noori uues ühiskonnas raskustega toime tulema. Teisalt ei saa ka tagasipöördumist lähteriiki tõlgendada üheselt allaandmisena. Näiteks Katja õde, kes pöördus tagasi Venemaale, asutas seal oma ettevõte ning on oma äritegevuses leidnud võimalusi ära kasutada Soomes veedetud aega. Lisaks saab ta Venemaal elades olla vanaisa lähedal. Suhteid Soomes elava noorema õe ja emaga kirjeldab ta suurest vahemaast hoolimata samuti lähedastena. Ta aitab oma õde ja ema võimalusel ka rahaliselt. Sugulaste abistamine ei toimu ilmtingimata suunal sihtriigist lähteriiki. See on tulnud välja ka teistes intervjuudes.

Siin uuritava materjali põhjal näib, et oma sünniriigist lahkumine Soome kolimise eesmärgil ei ole vanemale põlvkonnale tavaliselt unistuseks. Oma koduriigiga seob neid näiteks (ise ehitatud) maja, maakodu, sugulased, sõbrad ja sotsiaalne ümbruskond üldiselt. Paljudes intervjueeritud peredes, kus noorem põlvkond on kolinud Soome, on vanemad jäänud (vähemalt esialgu) lähteriiki. Osa vanema põlvkonna inimestest, kes on kolinud Soome, on teinud seda, järgnemaks oma lastele ja lastelastele, et olla oma järglaste lähedal. See peegeldab ka põlvkondade-vahelise hoolitsemise jätkuvat tähtsust.

Lähteriiki jäänud sugulased on mõnikord kogenud, et pereliikmed pole neid piisavalt informeerinud oma plaanidest teise riiki kolida. Heli, ühe 70aastase intervjueeritava kirjelduse järgi oli tema ainsa poja pere Soome kolimine temale suur katastroof. Tal oli väga raske selle mõttega harjuda, aga teisalt tundis ta, et ta ei saa teha midagi, et poja pere plaani kuidagi takistada:

Mul oli ikkagi suur katastroof, sellepärast, et siis ma jäin ju jumala üksipäini. Mul ei old enam kedagi, vot oleks, et nigu, nigu teisi lapsi oleks olema veel, et siis need teisedki jäävad siia või midagi niisugust. Tema mul ainuke oli, ja tema pere, ja mul teisi ei old, noh. Vend on maal, noh temaga nü̈̈d läbi ei käi midagi palju. Ja ega siis temast nagu abi ka pole midagi, noh [P: Mm]. Ta oli ikka nigu minu pere ja, ja, ja nii. Ja midagi teha pold. (Naine, elab Eestis. H39: 43.)

Heli kaotust suurendas tõik, et lisaks poja perele polnud tal Eestis selliseid sugulasi, keda ta oleks lähedaseks pidanud. Ka Heli mees oli surnud, samuti paljud temavanused sugulased ja sõbrad. Kõik see kasvatab üksildustunnet ning paneb mõtisklema Soome kolimisele. Poja 76aastane ämm Irja elab sa- 
muti Eestis ning naised helistavad üksteisele suhteliselt tihti, et vahetada infot laste pere käekäigu kohta. Sarnaselt Helile on ka Irja pidanud mõtlema Soome mineku peale, kuna ta tervis on kehv ja ta ainus tütar on Soomes. Irja poeg elab küll Eestis, tema lähedal, ent enda eest hoolitsemas näeks ta siiski parema meelega tütart. Selge, et minia pole tema silmis sama, mis tütar. Veelgi huvitavam aspekt on võib-olla see, et hoolitsemist nähakse eelkõige naiste, mitte meeste kohustusena.

Aga nü̈̈d ma olen mures, mis minust saab, ma olen juba vana. Kui ma enam ei jõua, siin on turg hästi lähedal, nü̈̈d ma käin vähemalt turul ja mul on jalad haiged, põlved on nii haiged. A kui ma enam hakkama ei saa, mis minust saab siis [naerab]. Siis pean minema Soome [naeran]. Tütar on ikka tütar, minia on ikka minia. Ega ma ei ütle, et ta mu vastu paha on, aga tütrega kuidagi suhtled rohkem [P: mjah]. (Ingeri päritolu naine, elab Eestis. H40: 61.)

Eakatel inimestel pole reisimine enam kuigi kerge, mida võibolla näitlikustab Vene Karjalas elava 80aastase mehe unelm saada (kui tervis lubab) Soomes enne surma veel üks kord kokku oma Rootsis elava vennaga (H38: 55). Mitmed eakad intervjueeritavad on rõhutanud, et nooremas eas on tore reisida küll, aga vanuse lisandudes on nad hakanud eelistama paikset elu. Paljud vanurid pole harjunud kasutama uuemat tehnikat, mis põhimõtteliselt võiks muuta suhtlemise eemal elavate pereliikmetega kergemaks. ${ }^{13}$ Ilmnes, et intervjuude läbiviimise ajal oli vanema põlvkonna inimeste peamiseks suhtlemisviisiks helistamine, kusjuures eakamad inimesed pigem ootasid kõnet lastelt ja lastelastelt, mitte ei helistanud nendele ise. 2013. aasta sügisel Eestist Soome kolinud peresid intervjueerides ${ }^{14}$ selgus, et see pole oluliselt muutunud, kuigi kümne aasta jooksul on kasutusele võetud uusi suhtlemiskanaleid, eriti noorema põlvkonna puhul. Vanem põlvkond on uue tehnika kasutamisel ettevaatlikum, paljudes peredes tuleb neile helistada tavalise telefoni, mitte Skype'ga. Kui ma küsisin ühelt 7aastaselt lapselt, kas ta räägib eesti vanaemaga telefonitsi tihti, vastas ta: "Ei, emme ei luba". Emale on laua- ja mobiiltelefonikõned liiga kallid ja helistamist on vaja piirata, sest vanaema ei kasuta Skype’i.

Paljud, kes alguses otsustasid koju jääda ega läinud sugulastele Soome järele, peavad vanuse lisandudes uuesti oma otsust kaaluma. Nad kardavad, et nad ei saa ilma välismaale kolinud lähedaste abita hakkama. Vananevate sugulaste eest hoolitsemine on Eestis ja Venemaal endiselt lähedaste ülesandeks. Vanadekodusid ei peeta arvestatavaks alternatiiviks ning tihti on küsimus ka rahas - eakate hooldekodud on liiga kallid. Kuna vanem põlvkond on omal ajal hoolitsenud laste ja lastelaste eest, võivad nad vastuteeneks oodata enda eest hoolitsemist. Inimesed on mures ka hoolduseta jäänud suguvõsa haudade pärast (haudade tähtsusest vt võrdlevalt ka Assmuth 2013). "Ma veel olen see, 
kes käib [---] veel neid haudasid harimas ja kui nüüd mina nüüd kaon, ma ei tea. Vaevalt et see Tarmo sealt Soomest neid tuleb puhastama. Ta ei saa oma isagi hauda siia puhastama tuldud, mis sa veel siis muud räägid" (H39: 135).

Soome läinud noorem põlvkond näeb hargmaist elu tavaliselt pigem positiivselt, kuigi nad mainivad ka neid (telefonis) taga nutvaid, lähteriiki lapselapsi igatsema jäänud vanaemasid. Vanavanemad muretsevad ka lastelaste keeleoskuse pärast. Mõnes peres on nii juba juhtunud, et vanavanematel ja lastelastel (või nende kaasadel) puudub ühine keelt. Oma tulevikuplaanid seovad noored pigem Soome või mõne kolmanda riigiga, aga mitte lähteriigiga. Kodumaale jäänud sugulased suhtuvad nt (ingeri)soomlaste ümberasumiskampaaniasse tavaliselt kriitilisemalt ning räägivad hargmaise elu ja Soome kolimise negatiivsetest külgedest üldse avameelsemalt. Nad on intervjuudes kirjeldanud ka protsessi, mille käigus nende Soome kolinud sugulased on Soomes elatud aja jooksul muutunud võõraks. Nad leiavad, et ümberasujad ei mõista enam päritoluriigi igapäevaelu. Ka rändlejad ise on mõnikord öelnud, et nad ei saaks enam tagasi pöörduda, sest elu päritoluriigis on niivõrd muutunud, et ühiskond on neile võõraks jäänud. Vahepeal kadunud võrgustikud ning uues asukohariigis omandatud töökogemus, haridus või ühiskondlikud normid võivad ka raskendada päritoluriigiga suhestumist (Kalev \& Jakobson 2013: 104).

\section{Piiride ületamine ja selle mõju perele}

Riigipiiri ületamine Eestist ja Loode-Venemaalt Soome on Nõukogude aja, 1990. aastate ning isegi kümne aasta taguse ajaga võrreldes muutunud järjest lihtsamaks. Euroopa Liidu kodanik saab nüüd Eesti ja Soome riigipiiri ületada märkamatult. Eesti liitumine Schengeni ühtse viisaruumiga 2007. aasta detsembris tähendab ühtlasi, et Eestisse saab tulla ka teistes Schengeni liikmesriikides välja antud viisadega. Alates 2003. aastast on Soomes lubatud topeltkodakondsus, mis tähendab, et Venemaa kodanikud ei pea oma kodakondsusest Soome kodakondsuse saamisel loobuma. 2002. aastal vastu võetud seaduse kohaselt võib Venemaa kodanikul olla ka teise maa kodakondsus, kuigi Venemaal käsitletakse sellist inimest alati ainult Vene kodanikuna. Intervjuude läbiviimise ajal mõjutasid Soome ümberasunud inimeste otsust Soome kodakondsus võtta või võtmata jätta paljuski veel piiride ületamisega seotud küsimused. Mitmed Venemaalt kolinud intervjueeritavad väitsid, et nad ei taotle Soome kodakondsust, sest Soome kodakondsetena peaksid nad Venemaale sugulastele külla sõiduks viisa taotlema. Piiride ületamine oli problemaatiline näiteks juhul, kui pere oli kolinud Venemaalt Soome ja neil oli Venemaa kodakondsus, aga samal ajal tahtsid nad külastada ka Eestis 
elavaid sugulasi. Kui neil oli ainult Vene pass, oli Eesti külastamiseks vaja viisat (H8, H27).

Suur osa soome juurtega Ida-Soome ümber asunud peredest on tulnud Vene Karjalast ning kontaktid Vene Karjala ja Ida-Soome vahel on tihedad. Riigipiirist hoolimata on Vene Karjalast tulnud intervjueeritavatel enda sõnul suhteliselt lihtne külastada päritoluriiki. Oluline ongi märgata vahemaade suhtelisust. Alati ei mängi olulist rolli niivõrd riigipiir, kuivõrd vahemaade pikkus ja nende läbimise lihtsus. Petrozavodskis elavate inimeste sõnul on neil Ida-Soomes elavaid sugulasi külastada lihtsam kui näiteks Peterburis või mõnes kaugemal asuvas Vene Karjala linnas või asulas elavaid sugulasi. Venemaale (ja Eestisse) minnakse ka tooma selliseid tarbekaupu ja toiduaineid, mida on Soomest kas raske hankida või mida peetakse kalliks, tuuakse ka sugulaste tehtud hoidiseid. Nagu eespool mainitud, ei ole pereliikmetele abi osutamine ühesuunaline.

Mõnikord on piiride ületamine osutunud keeruliseks või isegi võimatuks hetkel, mil seda on teha tahetud, ning see teema tõstatub ka intervjuudes. Eriti 1990. aastatel toimunud ümberasumisega seoses on inimesed mõnikord kartnud, et piirid võidakse jälle sulgeda. 1991. aastal oligi Soome ja Venemaa vaheline piir suletud kolm kuud, ja üks intervjueeritavatest, umbes 45aastane naine, on järgnevalt kirjeldanud oma ahastust olukorras, kus ta perekond on oma sugulastest lahutatud, teadmata, millal nad saavad jälle piiri ületada: "Aga peale seda oli raske, kui tulime, aastal 1991, kui oli riigipööre ja nii edasi ja piirid olid suletud ja tuli selline otsus Soomest, et ei tohi riigist väljuda mitte kuskile ja, see oli raske. Ma ei võinud mõelda, et ei saaks kunagi näha ja kohtuda oma sugulastega" (H15: 66).

Oma hirmudest on rääkinud nii elukohta vahetanud inimesed ise kui ka kodumaale jäänud sugulased, kes näiteks kirjeldavad oma hirme ümberasunud sugulaste saatusega seoses. 70aastane Heli on kirjeldatud olukorda, kus Soome läinud sugulastega ei ole alguses ühendust hoitud sel määral, nagu oleks tahetud, just nimelt sel põhjusel, et kardeti nendest kontaktidest pahandusi. Näiteks ei julgenud nad kirjutada või Eestisse tulla koduigatsusest hoolimata, sest kartsid, et äkki sunnitakse neid Eestisse tagasi tulema või siia jääma (H39: 99, 101). Mainitakse ka, et helistamine on kallis, mis võib mõjutada mõne pere ühenduse hoidmist.

Pihla: Kas te hoiate palju ühendust või? (H: Ah?) Et palju hoiate ühendust nendega, et helistate ja?

Heli: No nüid. No varem oli ka nii, et ei saanudki olla, aga nü̈̈d on siis, noh aga ega siin ei saa ka palju midagi, helistada palju ei saa. Kõik on kallis. Noh, nü̈̈d nad on akand nagu, rohkem, rohkem nagu siin ka käima ja siis ikka tulevad siia ja kõik noh, on nagu nagu paremaks läind. Aga 
vahepeal läksid siin aastad mööda nii, et me ei saand üldse kokku. Mõni kiri võibolla tuli ja oligi kõik. Ja ega siis ma ei tea telefoniga ka palju helistada ei saand midagi, sest noh lihtsalt ma ei tea, nemad ise pelgasid seda jah, no minul pold häda midagi, aga nemad lihtsalt ei helistanud. (Naine, elab Eestis. H39: 45.)

Hirmud pärinevad paljuski Nõukogude Liidu ajast, mil võimud kontrollisid reisimist ja ühenduse hoidmist välismaal elavate sugulastega. Ka juhul, kui inimesed ei ole seda ise kogenud, on neil olemas vanema põlvkonna vahendatud kogemus sellest. Üks 30aastane naine jutustas, kuidas ta vanaisa sai 1970. aastatel kirja temaga sama perekonnanime kandvalt inimeselt, kes oli sõja järel sattunud Austraaliasse ja otsis nüüd oma sugulasi. Vanaisa kartis oma pere pärast ja jättis kirjale vastamata ning hoopis hävitas selle (H33: 42). Välismaal elavatest sugulastest oli parem mitte rääkida: "Vanaonu veenis ema, et ta ei räägiks sellest, et meil on sugulasi Soomes, sest ta oleks muidu lastud töölt lahti. Ei tohtinud omada sugulasi välismaal. See on ka üks põhjustest, miks praegu on soov reisida ja maailmas ringi vaadata" (H12: 26). Ühes rühmaintervjuus öeldakse otse, kuidas ingeri pere kartis esimeste hulgas Venemaalt Soome õppima läinud laste pärast. "Sest teadsime, mis juhtus meie vanematega [---] et ühtäkki suletakse piir, sellised kartused olid. [---] Hirmud olid igal juhul säilinud vanematelt, vähemalt meie põlvkonnale. Et nendega juhtus nii, ja nemad kandsid edasi meile, selle hirmu" (H31: 34). Mõned Vene Karjalas intervjueeritud inimesed ei ole andnud luba intervjuu arhiveerimiseks, ning selle otsuse tagant võib ilmselt leida analoogilisi hirme. Üks 81aastane mees ütles, et ta kardab, et intervjuu sattumine vaenlase kätte võiks põhjustada probleeme ta Soomes elavatele sugulastele, kuigi ta nõustus samas, et ei ole intervjuu jooksul öelnud Soome kohta midagi halba (H28).

Piiriga on seotud paljud võimuaspektid - kellel on kontroll piiri ületamise võimaluste üle. Ka tänapäeval ei saa rääkida vabast liikumisest: liikumine ja piiride ületamine on mõnele raskem, mõnele kergem. Piiride ületamise võimalus sõltub näiteks sellest, millise riigi pass reisijal on ning milline on tema staatus asukohariigis. Umbes 50aastane naine on intervjuus kirjeldanud olukorda, kus tema liikumist Venemaale on piiratud, sest ta on Soomes registreerunud töötuks. Ta ütles, et ootab pensionipõlve, et siis saaks vabamalt käia Venemaal ja veeta seal pikemaid perioode oma lapse ja lapselapse juures. Hierarhia väljendub ka mõistetes, mida kasutatakse inimeste liikumisest avalikkuses rääkides - mobiilsusega viidatakse eliidi ja haritud inimeste liikumisele, töölisrände puhul räägitakse negatiivsemas toonis immigratsioonist (Bryceson \& Vuorela 2002: 7-8). See kajastub ka rändlejate enesemääratluses: tundub, et osa neist ei seosta end immigrantidega (ega taha, et teisedki seda teeksid) ja räägivad immigrantidest pigem kui teistest. 
Ametnikele lisaks on piiriületust vähemalt kaudselt kontrollinud ka muud ringkonnad. Soomlaste ümberasumiskampaania ajal on kohalikud Ingeri liidud võtnud vastu Soome elamaasumise avaldusi. Minu intervjueeritavad on vihjanud kahtlustele, et liidu esimehed on oma positsiooni kuritarvitanud, võimaldades oma sugulastele ja tuttavatele parema positsiooni Soome mineku järjekorras. ${ }^{15}$ Inimesed on väljendanud ka pettumust, et neil pole olnud võimalik järgneda oma vanematele ja õdedele-vendadele, vaid nad peavad ootama järjekorras või otsima mõne muu legaalse põhjuse Soome kolimiseks: nagu mainitud, pere taasühendamiseks loetakse väljastpoolt Euroopa Liitu tulevate inimeste puhul pereliikmeks ainult alaealised lapsed ja abikaasa. ${ }^{16}$

Mõned intervjueeritute tuttavad või pereliikmed on pärast mõnda aega Soomes elamist otsustanud tagasi pöörduda lähteriiki, näiteks abielulahutuse tagajärjel vms. Lahutuse järel on ka juhtunud, et piiri(de) ületamist on lähteriiki naasvale endisele abikaasale proovitud teha raskeks või isegi võimatuks. Näiteks 16aastane tüdruk kirjeldas olukorda oma peres pärast vanemate lahutust, mil lapsed jäid emaga Soome, isa aga pöördus tagasi Venemaale, järgnevalt: "Isa poleks tahtnud minna [tagasi Venemaale], ja siis ema tegi mingi sellise süsteemi, et teda ei lastud Soome [tulla lapsi vaatama], neil olid hirmsad tülid ja puha. Ema pärast isa ei saanud tulla, ta on ikka hirmus kibestunud tema peale sellepärast" (H23: 65). Tihtipeale aktualiseeruvad piiride ületamisega seotud probleemid kriisiolukordades, kui pole aega, võimalust ega jaksu formaalsustega tegeleda. Näiteks lähedase ootamatu haiguse, õnnetuse või surma puhul oleks kiiresti vaja teise riiki saada, aga selleks pole võimalik ette valmistuda. 30aastane Anni on kirjeldanud üsna detailselt olukorda, mis pani ta uuesti kaaluma Soome kolimise võimalust. Soome olid asunud elama ta õde, vend, ema ja kõige viimasena ka isa. N.ö tuumperest oli Venemaale jäänud ainult tema (lapsi või elukaaslast tal polnud). Küsisin, kas ta ei ole mõelnud Soome kolimise peale:

Anni: No ütleme nii, et kui minu vanemad kolisid, tähendab kui mu isa kolis, ta proovis ka mind veenda, aga mind hoidsid siin paljud asjad, ütleme nii. Ei olnud erilist tahtmist sõita. Hiljem, kui ta suri, sain aru, et mu pere on seal, tähendab mul on raske sõita edasi-tagasi, tahaks, et saaks iga hetk kohtuda ema, [õe, vennaga]. Meil juhtus nii, et kui isa suri, olin siin [Venemaal] ja mul ei olnud isegi viisat. Selline olukord oli, kõik mõtlesid sellele ja pärast tekkis, mitte ainult et soov, vaid lausa tungiv vajadus sinna ära minna, aga ei võetud vastu. (Naine, elab Vene Karjalas. H33: 15.)

Materjali hulgas leidub ka humoorikaid lugusid piiride ületamise raskustest seoses sugulaste külastamisega, mis näitab inimeste võimekust naerda tagant- 
järele oma raskuste üle - loos kõneldava sündmuse toimumise hetkel polnud see kindlasti naljakas. Eestis elav Irja jutustas mulle, kuidas ta tahtis külastada Soome elama läinud sugulasi. Tal oli vaja kutset, mida hiljuti Soome kolinud tütre pere ei saanud talle ise veel saata. Kutse saatis üks pere tuttavatest. Piiril, kui oleks olnud vaja kutset näidata, ei leidnud aga Irja seda mitte kuskilt. Ka ei suutnud ta meelde tuletada kutse saatnud inimese nime. Tal õnnestus siiski üle piiri saada, ja hiljem oli hea selle juhtumi üle koos naerda (H40: 56).

Konkreetsed piirid figureerivad ka fotodel, mille abil on võimalik jagada ümberasumise kogemust päritoluriiki jäänud sugulastega. Heli, kelle poeg oli perega Soome läinud, näitas mulle palju pilte poja pere teekonnast Soome ja piiril poseerimist; siis tähistamas oma esimesi jõule ja poja sünnipäeva Soomes kohe sinna kolimise järel ja veel palju muidki fotosid poja perest Soomes (H39: 103-104, 107). Neid fotosid näidates jutustas ta sündmustest nii, nagu oleks ka ise neis osaline olnud.

Kui pereliikmed ei ela samas riigis ja neil puudub ühine argipäev, võib juhtuda, et peresuhted ja kohustused tuleb uuesti üle vaadata ja läbi arutada. Võib väita, et selles situatsioonis lugude jutustamine, fotode vaatamine ja viimasel ajal järjest rohkem ka sotsiaalmeedias suhtlemine võivad vähemalt mingil määral asendada tavapärast vahetut suhtlemist, aidates kaasa peretunde säilimisele hargmaises kontekstis. Pereelu mõned aspektid - näiteks üksteise eest hoolitsemine - nõuavad siiski pereliikmete kohalolekut ja seovad inimesi kohaga väga konkreetsel moel. Mõnikord on võimalik rääkida eemalt hoolitsemisest, aga hooldamisega seotud tegevused nõuavad enamasti vahetut suhtlemist, füüsilist kontakti, aega ja kohalolekut (vt Zechner 2008: 36-37), millest kodumaale jäänud vanemad sugulased kõige rohkem puudust tunnevad.

\section{Kokkuvõtteks}

Migratsiooniuurimustes on pikemat aega tähelepanu pööratud eelkõige elukohariiki vahetanud inimeste kohanemisele uue asukohamaa majandusliksotsiaalse ja kultuurilise keskkonnaga ning ümberasumise tõmbe- ja tõuketeguritele. Integratsioonikeskses uurimuses on lähtutud oletusest, et uus asukohariik on (või peaks olema) tulijatele uus kodumaa. Inimeste hargmaistele võrgustikele või mitmepaiksusele ei ole selles kontekstis tähelepanu pööratud või on seda peetud pigem erandiks (Rolshoven 2007: 21). Viimase paarikümne aasta jooksul on hakatud rohkem rõhutama inimeste paralleelseid seoseid kahe või mitme riigiga, ning transnatsionaalsus on tõusnud üheks keskseks põhisuunaks interdistsiplinaarses migratsiooniuurimises (vt Vertovec 2007: 961-964). Ka kultuuriuurijad on järjest rohkem pööranud tähelepanu inimeste, 
ideede ja asjade liikumisele, protsessidele ning paindlikkusele, mida on märgata ka terminoloogias trans-eesliite kasutamise lisandumisena (Bendix \& Löfgren 2007: 7). Rahvusvahelist migratsiooni ja hargmaisust puudutavates uurimustes on etnograafilisel käsitlusviisil tähtis roll üksikisikute kogemustele ning migratsiooniga seotud kommetele ligipääsemiseks.

Antud uurimuses analüüsiti intervjuude abil kogutud materjali toel mitmepaiksete perekondade kogemusi Eesti, Soome ja Loode-Venemaa piiriüleses ruumis. Artiklis vaadeldi hargmaiste perekondade lugusid piiridest ja jutustamist piiride ületamisest või ületamatusest. Eesmärk oli uurida mobiilsusest jutustamist ja hargmaist perekonda, lähtudes mitte ainult täiskasvanud rändlejate perspektiivist, vaid erinevate pereliikmete vaatevinklist. Huviväljas oli eelkõige migratsiooniga seotud muutused peres ning küsimus, milline on perekondliku jutustamise roll hargmaisusega kaasnevate väljakutsetega toimetulekul.

Analüüsist ilmnes, et mobiilsusest jutustavad eri jutustajad eri situatsioonides erinevalt. Ka ühe intervjuu jooksul on näiteks ümberpaiknemise põhjusi kirjeldatud mitmel viisil, viidates nii juhuslikkusele kui ka kaalutletud otsusele. Vaadeldes hargmaiseid peresid ja nende liikmete rändenarratiive, võib märgata, et täiskasvanute ja noorte lugudes rõhutatakse erinevaid aspekte: noorte juttudes on juhuslikkus kesksemal positsioonil. Kodumaale jäänud inimesed on valmimad rääkima ka hargmaise pereelu negatiivsetest külgedest ning probleemidest pereliikmete vahel ühenduse hoidmisel. Ümberasumisest ja hargmaisest pereelust jutustamist mõjutab sugulaste ja tuttavate ring ning ümbritsev ühiskond, mille liikmete seisukohtade, ootuste ja kriitikaga peab jutustaja samuti arvestama. Ebaõnnestunud migratsioonist räägitakse harva, nagu ka pereelu negatiivsetest külgedest, aga kui nendest räägitakse, siis pigem luuakse endale positiivne võtmenarratiiv, mis aitab elus edasi minna. Sündmuslugude kaudu võib olla lihtsam rääkida ka oma tunnetest ja hoiakutest, mida muidu oleks raske sõnadesse panna. Mõnikord sõnastatakse oma tundeid ka teiste kaudu, näiteks laste kogemusi kirjeldades. Perepärimusele omaselt on enda ja pereliikmete kogemuste piir mõnikord hajus.

Esile tuli ka see, et intervjuukäigus jutustatud rändenarratiivides keskendutakse eelkõige lähiminevikus toimunud ümberasumisele. Lood varasemate põlvkondade visadusest ja vaprusest võivad ka kohanemisel abiks olla, raskustele viidates rõhutatakse nimelt hakkamasaamist. Intervjueeritud on üldjoontes teadlikud ka pere minevikus toimunud ümberasumistest, kuigi sunnitud migratsioonist pole alati avameelselt räägitud isegi pereringis. Hoolimata sellest on kogemused ja kohati ka minevikust pärit hirmud pärandatud ka nooremale põlvekonnale, kellel hirm aktualiseerus näiteks piiride sulgemise kartuses. Jutustustes antakse edasi ka selliseid piiride ületamisega seotud kogemusi ja raskusi, mis võivad ajapikku muutuda naljakateks. Märkimisväärselt palju on 
lugusid esimesest Soomes käigust, milles kajastub oma ja võõra vaheline dünaamika. Kui osa pereliikmetest lahkub kodumaalt, võivad ka nemad muutuda lähteriiki jäänud inimeste silmis võõraks. Seda soodustavad raskused ühenduse hoidmisel, millele on intervjuudes vihjanud eriti vanema põlvkonna inimesed. Peretunde loomisel ja säilimisel hargmaises kontekstis on väljakutseid, mis jäävad iga konkreetse pere lahendada neile võimalikul ja eripärasel moel.

\section{Kommentaarid}

1 Artikkel valmis grandi ETF 9271, institutsionaalse uurimisteema "Traditsioon, loovus ja ühiskond: vähemused ja alternatiivsed diskursused" (IUT2-43), Euroopa Liidu Euroopa Regionaalarengu Fondi (Kultuuriteooria Tippkeskus) ja Kone sihtasutuse (projekt "Üle piiride liikuvad perekonnad: migratsioon Euroopas laste vaatevinklist") toel. Autor tänab Daniel E. Allenit artikli ingliskeelse kokkuvõtte toimetamise eest.

2 Inimesed ja pered on liikunud ka varasematel aegadel, aga käesolevas artiklis keskendun perede mobiilsusele eelkõige alates 1990. aastatest. Nagu Arjun Appadurai on kirjutanud, peame ka suhteliselt stabiilseid rühmi (sh pere) uurides arvestama neid laiemas mastaabis läbiva mobiilsusega ning tänu massimeediale ja globaliseerumisele ka liikumist puudutavate fantaasiate kasvamisega. On suurenenud kujuteldavate elude hulk, mis võib mõnikord tekitada terava kontrasti ettekujutuse ja sotsiaalse reaalsuse vahel ning soov emigreeruda on suurem. (Appadurai 1996: 34, 53-54.) Kuna ühenduse hoidmine ja liikumine mitme maa vahel on kergemaks muutunud, on rändlejad varasemast tihedamalt seotud mitme maaga.

3 Diasporaa osaks on teinekord saanud ka inimesed, kes pole antud momendil füüsiliselt liikunud mitte kuskile. Tiiu Jaago (2011) on venekeelseid eluloojutustusi analüüsides juhtinud tähelepanu sellele, kuidas nõukogudeaegsed sisserändajad on Eesti taasiseseisvumise järel muutunud migrantideks. Jutustajad ise kõnesolevat rännet valdavalt migratsioonina ei käsita, aga riigipiiri muutumisel on nad avastanud, et elavad nüüd "diasporaas".

4 Hargmaise perekonna puhul pole ilmtingimata tegemist segaperega; hargmaine pere võib olla sama hästi üherahvuseline pere, mille kõik liikmed lihtsalt ei ela ühes riigis.

5 Mitmepaiksetest välitöödest ja välitööde iseloomu muutumisest seoses inimeste kasvava liikuvusega vt Marcus 1995; Wiklund 2012.

6 Materjali, millel artikkel põhineb, olen kogunud hargmaiseid peresid puudutava doktoritöö jaoks (folkloristika, Ida-Soome ülikool).

7 Kümne pere puhul on intervjueeritud mitut pereliiget, kuue puhul vaid üht pereliiget. 15 intervjueeritavat olid intervjuu tegemise hetkel nooremad kui 30 aastat, 12 olid 30-49 aastat vanad, ja 18 olid 50aastased või vanemad.

8 Mõni on näiteks asunud alguses Soome õppima või töötama ja hiljem leidnud endale kaasa või otsustanud jääda, kasutades ingerlaste naasmisprogrammi pakutud võimalust.

9 Vabatahtliku ja sunniviisilise migratsiooni eristamise problemaatilisusest, vt ka Jürgenson \& Kumer-Haukanõmm \& Tuisk 2011. 
${ }^{10}$ Intervjuude viiteid tähistab H (H1-H40), sellele järgnev number viitab konkreetsele kohale litereeritud intervjuus. Intervjueeritavate ja teiste intervjuudes mainitud inimeste puhul on artiklis kasutatud pseudonüüme.

${ }^{11}$ Esimeste hulgas saabunud remigrantide staatus oli enamasti üsna erinev võrreldes hiljem tulnutega, kuigi nende erilist positsiooni on mõnes intervjuus võib-olla üleliia rõhutatud, justkui erineksid ka nende motiivid Soome tulekuks oluliselt hiljem tulnute põhjustest. Näiteks ühe immigrantide nõustaja arvates ei teadnud esimesed immigrandid midagi sotsiaalkindlustusest: esimesed 1990. aastatel saabunud ingerisoomlased tulid ainult sellepärast, et nad tundsid, et nende juured on Soomes, "nad tundsid oma identiteeti, et nad on soomlased. Ja neid koheldi halvasti Nõukogude Liidus ja sellepärast nad tulid kodumaale, tulid oma etnilisele kodumaale" (H19: 28).

${ }^{12}$ Bönisch-Brednichi (2003: 126) järgi ei meeldi inimestele rääkida ebaõnnestunud migratsioonist. Olen nõus, kuigi mõningaid selliseid lugusid on mulle ka räägitud, tavaliselt siiski siis, kui kriitiline olukord on juba mingi lahenduse leidnud.

${ }^{13}$ Uuema meedia kasutamise eeltingimusteks on nt juurepääs sellele, taskukohasus ning meediakirjaoskuse olemasolu (vt Madianou \& Miller 2012: 171).

${ }^{14}$ Kone sihtasutuse rahastatav projekt "Üle piiride liikuvad perekonnad: migratsioon Euroopas laste vaatevinklist".

15 Ühe intervjueeritud naise ema ei võetud esimese palve peale üldse tagasipöördujate järjekorda (mis on eelduseks Soome kolimisele), vaid alles pool aastat hiljem, kui ta läks uuesti kohale ning nõudis tungivamalt järjekorda saamist (H33: 52).

${ }^{16}$ Peab nentima, et inimesed on näidanud üles innovatiivsust, mõeldes erinevatele variantidele, kuidas piiri ületada saaks. Üks ema on naljaga pooleks rääkinud, kuidas nad proovisid tütrele abikaasat leida, et ka tütar saaks pere järel Soome kolida (H1: 21). Lihtsustamaks oma elu (piiride ületamine, elamisload), võivad ka erinevatest riikidest pärit noorpaarid abielluda kiiremini, kui nad muidu oleksid seda teinud (vt nt H33: 136).

\section{Allikad}

H1-H40: Pihla Siimu aastatel 2000-2004 kogutud materjal, autori valduses kuni projekti lõpuni. Uurimismaterjal koosneb välitööpäevikutest (I-XVII) ja neljakümnest intervjuust, mis on tehtud Soomes, Eestis ja Vene Karjalas. Kümne pere puhul on intervjueeritud mitut pereliiget, kuue puhul on intervjueeritud vaid üht pereliiget. 15 intervjueeritavatest olid intervjuu tegemise hetkel nooremad kui 30 aastat, 12 olid vanuses 30-49 aastat, 18 olid 50aastased või vanemad. Intervjuud on läbi viidud kas eesti, soome või vene keeles. Võrdluseks on kasutatud materjale välitöödelt (osalusvaatlus ning intervjuud), mille autor on läbi viinud 2013. aasta sügisel Lõuna-Soomes eesti päritolu lastega peredes.

\section{Kirjandus}

Appadurai, Arjun 1996. Modernity at Large: Cultural Dimensions of Globalization. Minneapolis \& London: University of Minnesota Press. 
Assmuth, Laura 2013. Asymmetries of Gender and Generation in a Post-Soviet Borderland. Bacas, Jutta Lauth \& Kavanagh, William (toim). Border Encounters. Asymmetry and Proximity at Europe's Frontiers. New York \& Oxford: Bergham Books, lk 139-164.

Bendix, Regina \& Löfgren, Orvar 2007. Double Homes, Double Lives? Ethnologia Europaea. Journal of European Ethnology 37 (1-2), lk 7-15.

Bryceson, Deborah Fahy \& Vuorela, Ulla 2002. Transnational Families in the Twentyfirst Century. Bryceson, Deborah \& Vuorela, Ulla (toim). The Transnational Family: New European Frontiers and Global Networks. Oxford; New York: Berg Publishers, lk 3-29.

Bönisch-Brednich, Brigitte 2003. Ränne ja jutustamine. Mäetagused 23, lk 114-129 (http://www.folklore.ee/tagused/nr23/migrat.pdf-10. märts 2014, doi: 10.7592/MT2003.23. migrat).

Chamberlain, Mary \& Leydesdorff, Selma 2004. Transnational Families: Memories and Narratives. Global Networks 4 (3), lk 227-241.

Davydova, Olga 2002. Interaktiivista identiteettipeliä - havaintoja paluumuutosta Suomeen. Laihiala-Kankainen, Sirkka \& Pietikäinen, Sari \& Dufva, Hannele (toim). Moniääninen Suomi: kieli, kulttuuri ja identiteetti. Jyväskylä: Soveltavan kielentutkimuksen keskus, Jyväskylän yliopisto, lk 154-168.

Davydova, Olga 2004. Etnisyyspuhe Suomen kynnyksellä. Paluumuuttajien suomalaisuuden muodostuminen. Avaldamata folkloristika litsensiaaditöö, Joensuu ülikool.

Faist, Thomas 2000. The Volume and Dynamics of International Migration and Transnational Social Spaces. Oxford: Clarendon Press (doi: 10.1093/acprof:oso/9780198293910.001.0001).

Golbert, Rebecca 2001. Transnational Orientations from Home: Constructions of Israel and Transnational Space among Ukrainian Jewish Youth. Journal of Ethnic and Migration Studies 27 (4), lk 713-731 (doi: 10.1080/13691830120090467).

Huttunen, Laura 2002. Kotona, maanpaossa, matkalla. Kodin merkitykset maahanmuuttajien omaelämäkerroissa. Suomalaisen Kirjallisuuden Seuran Toimituksia 861. Helsinki: Suomalaisen Kirjallisuuden Seura.

Hyvärinen, Matti 2006. Kerronnallinen tutkimus. (http://www.hyvarinen.info/material/ Hyvarinen-Kerronnallinen_tutkimus.pdf - 10. märts 2014).

Jaago, Tiiu 2011. Nõukogudeaegne migratsioon ja selle ilmnemine omaelulugudes. Acta Historica Tallinnensia 17, lk 140-149. (http://www.kirj.ee/public/Acta_hist/2011/issue_2/ acta-2011-17-140-149.pdf, doi: 10.3176/hist.2011.2.09 - 10. märts 2014).

Jürgenson, Aivar \& Kumer-Haukanõmm, Kaja \& Tuisk, Astrid 2011. Vabatahtlik ja sunniviisiline ränne eesti migratsiooniloos. Acta Historica Tallinnensia 17, lk 3-15. (http://www.kirj.ee/public/Acta_hist/2011/issue_2/acta-2011-17-3-15.pdf - 10. märts 2014, doi: 10.3176/hist.2011.2.01).

Kaivola-Bregenhøj, Annikki 2008. Kogemus ja tõlgendus: kuidas väljendatakse jutustamisel emotsiooni. Västrik, Ergo-Hart (toim). Kes kõlbab, seda kõneldakse. Pühendusteos Mall Hiiemäele. Eesti Rahvaluule Arhiivi toimetused 25. Tartu: Eesti Kirjandusmuuseumi Teaduskirjastus, lk 157-168.

Kalev, Leif \& Jakobson, Mari-Liis 2013. Hargmaisus Eesti-Soome ruumis. Acta Politica Estica 4, lk 95-113 (http://publications.tlu.ee/index.php/actapoliticaestica/article/ view/108/97 - 10. märts 2014). 
Körber, Karen 2012. So Far and Yet So Near. Present-Day Transnational Families. Ethnologia Europaea 42 (2), lk 12-25.

Laki ulkomaalaislain 48 §:n muuttamisesta 57/2011. [Välismaalaste seaduse muutmise seadus 57/2011.] (http://www.finlex.fi/fi/laki/alkup/2011/20110057 - 10. märts 2014.)

Liebkind, Karmela \& Mannila, Simo \& Jasinskaja-Lahti, Inga \& Jaakkola, Magdalena \& Kyntäjä, Eve \& Reuter, Anni 2004. Venäläiset, virolaiset, suomalaiset: Kolmen maahanmuuttajaryhmän kotoutuminen Suomeen. Helsinki: Gaudeamus.

Maahanmuutto- ja pakolaispoliittinen toimikunta 1996. Inkerinsuomalaisten paluumuutto: maahanmuutto- ja pakolaispoliittisen toimikunnan osamietintö. Sisäasiainministeriön julkaisu. (Tark. 2. p.) Helsinki: Sisäasiainministeriö.

Madianou, Mirca \& Daniel, Miller 2012. Polymedia: Towards a new theory of digital media in interpersonal communication. International Journal of Cultural Studies 16 (2), lk 169-187 (http://ics.sagepub.com/content/16/2/169 - 10. märts 2014, doi: 10.1177/1367877912452486).

Marcus, George E. 1995. Ethnography in/of the World System: The Emergence of MultiSited Ethnography. Annual Review of Anthropology 28, lk 95-117 (http://www.dourish. com/classes/readings/Marcus-MultiSitedEthnography-ARA.pdf - 10. märts 2014).

Martikainen, Tuomas 2007. Maahanmuuttajaväestön sukupuolittuneisuus, perheellistyminen ja sukupolvisuus. Martikainen, Tuomas \& Tiilikainen, Marja (toim). Maahanmuuttajanaiset: Kotoutuminen, perhe ja työ. Väestöntutkimuslaitoksen julkaisusarja D46/2007. Helsinki: Väestöliitto, lk 38-67.

Martikainen, Tuomas \& Sintonen, Teppo \& Pitkänen, Pirkko 2006. Ylirajainen liikkuvuus ja etniset vähemmistöt. Martikainen, Tuomas (toim). Ylirajainen kulttuuri: Monikulttuurinen Suomi 2000-luvulla. Tietolipas 212. Helsinki: Suomalaisen Kirjallisuuden Seura, lk 9-41.

Ong, Aihwa 1999. Flexible Citizenship: The Cultural Logics of Transnationality. Durham \& London: Duke University Press.

Povrzanović Frykman, Maja 2004. Transnational Perspectives in Ethnology: From 'Ethnic' to 'Diasporic' Communities. Povrzanović Frykman, Maja (toim). Transnational Spaces: Disciplinary perspectives. Malmö: Malmö University (IMER), lk 77-100 (http:// dspace.mah.se/bitstream/handle/2043/5269/Transnational\%20Spaces.pdf?sequence=2 10. märts 2014).

Povrzanović Frykman, Maja 2008. Beyond Culture and Identity. Places, Practices, Experiences. Ethnologia Europaea. Journal of European Ethnology 38 (1), lk 13-22.

Reinvelt, Riina 2002. Ingeri elud ja lood. Kultuurianalü̈tiline eluloouurimus. Studia Ethnologica Tartuensia 5. Tartu: Tartu Ülikool.

Rolshoven, Johanna 2007. The Temptations of the Provision. Multilocality as a Way of Life. Ethnologia Europaea. Journal of European Ethnology 37 (1-2), lk 17-25.

Safran, William 1991. Diasporas in Modern Societies: Myths of Homeland and Return. Diaspora 1 (1), lk 83-99. 
Zechner, Minna 2008. Care of Older Persons in Transnational Settings. Journal of Aging Studies 33 (1), lk 32-44 (http://www.sciencedirect.com/science/article/pii/ S0890406507000655 -10. märts 2014, doi: 10.1016/j.jaging.2007.02.002).

Tilastokeskes 2012a. Kansalaisuus iän ja sukupuolen mukaan maakunnittain 1990-2012 (http://193.166.171.75/Dialog/varval.asp?ma=020_vaerak_tau_101_fi\&ti=Kansalaisuus +i\%E4n+ja+sukupuolen+mukaan+maakunnittain+1990+\%2D+2012\&path=../Database/ StatFin/vrm/vaerak/\&lang=3\&multilang=fi -10 . märts 2014).

Tilastokeskes 2012b. Syntymävaltio iän ja sukupuolen mukaan maakunnittain 19902012 (http://193.166.171.75/Dialog/varval.asp?ma=040_vaerak_tau_103_fi\&ti=Syntym $\% \mathrm{E} 4$ valtio+i\%E4n+ja+sukupuolen+mukaan+maakunnittain+1990+\%2D+2012\&path=../ Database/StatFin/vrm/vaerak/\&lang=3\&multilang=fi -10 . märts 2014).

Tilastokeskes 2012c. Kieli iän ja sukupuolen mukaan maakunnittain 1990-2012 (http://193.166.171.75/Dialog/varval.asp?ma=030_vaerak_tau_102_fi\&ti=Kieli+i\%E4n+ ja+sukupuolen+mukaan+maakunnittain+1990+\%2D+2012\&path=../Database/StatFin/ $\mathrm{vrm} /$ vaerak/\&lang=3\&multilang=fi -10 . märts 2014).

Vertovec, Steven 2007. Introduction: New directions in the anthropology of migration and multiculturalism. Ethnic and Racial Studies 30 (6), lk 961-978 (doi: 10.1080/01419870701599416).

Wahlbeck, Östen 2002. The Concept of Diaspora as an Analytical Tool in the Study of Refugee Communities. Journal of Ethnic and Migration Studies 28 (2), lk 221-238 (doi: 10.1080/13691830220124305).

Wiklund, Lisa 2012. Creative Cosmopolitanism. New Fields of Work Require New Fieldwork. Hirvi, Laura \& Snellman, Hanna (toim). Where is the Field? The Experience of Migration Viewed through the Prism of Ethnographic Fieldwork. Studia Fennica Ethnologica 14. Helsinki: Finnish Literature Society, lk 109-127.

\section{Summary}

\section{Transnational families: Stories about moving and staying put}

\section{Pihla Maria Siim}

Keywords: border, family, migration, storytelling, transnationality

In the research into migration, push and pull factors have for a long time been in the foreground, in addition to integration and the acculturation of mobile people settling in receiving countries. The starting point for integration-centred research has been the fact that the new country of residence is, or should be, also a new home country for the migrants. In this context, the transnational networks of migrants have not received enough attention, multi-locality being regarded rather as an exception. However, during the last two decades researchers have started to stress the parallel relations that people have to two or more states, meaning that it is possible even to talk about a transnational turn in the interdisciplinary field of migration studies. 
Drawing on fieldwork material, this article explores the experiences of multi-local families, whose members live some or most of the time separated from each other, in the transnational social space in an Estonian-Finnish-northwest-Russian context. The main research material consists of forty interviews the author has made between the years 2001 and 2004. Interviewees are former Soviet immigrants living in Finland, on the one hand, and their family members living in the country of origin (Russian Karelia and Estonia), on the other.

By using narrative research methods, the author explores narratives of migration and border crossing - the possibilities and difficulties related to going beyond them. The aim has been to study transnational family life and narrating mobility from the perspective of different family members, taking into account the experiences of relatives who stay behind as well as those of children, in addition to adult migrants. The author is especially interested in the changes in family (life) caused by migration and the role of family storytelling in coping with these challenges.

Mobility is narrated differently depending on the situation and the position of the narrator. Even during the same interview the motivations for relocation are described in different ways, picturing both a spontaneous move and carefully thought out decision. Different aspects are stressed in the migration stories told by adult family members as compared to those of children, unexpectedness of migration being more important in the narratives of the younger generation. Family members staying in the country of origin are more willing to talk about the negative sides of transnational family life, as well as about the problems encountered when keeping in touch with relocated family members. When narrating migration and transnational family life, people have to take into consideration the standpoints, expectations and possible disapproval of their relatives, acquaintances and members of surrounding societies. People rarely talk about unsuccessful migration or about the negative sides of family life, although these aspects can also be moulded into a positive key narrative that helps a person continue with his/ her life. With the help of stories, it can also be easier to put into words feelings and attitudes that would otherwise be difficult to express. Sometimes feelings are also described through the experiences of other family members, for example children.

The migration stories told during the interviews concentrate on relocations that took place in the recent past. When talking about the forced relocations or other hardships in the family history, the stress is on survival, on coping with problems. The stories about the persistence and courage of previous generations can also help people to cope with the present-day difficulties. Interviewees are generally aware of the historical relocations of their family members, although forced migration has not always been openly talked about even in the family circle. Along with experiences, fears related to them are often passed to younger generations. Interviewees have, for example, mentioned their fears related to the possible closing of borders. A number of stories also describe people's first visits to Finland, reflecting the dynamics between their 'own' and the 'foreign' worlds. When family members move to other countries, they can become foreigners in the eyes of the relatives who remain. This can be fostered by the problems related to keeping in touch, which have been touched upon especially by older family members who stay in the country of origin. Keeping up a cohesive family feeling across national borders brings its own challenges, with which transnational families must deal. 